\title{
Gene patenting and licensing: the role of academic researchers and advocacy groups
}

David H. Ledbetter, PhD

\begin{abstract}
The subject of human gene patenting has received a great deal of media attention, and many individuals and professional societies (including the American College of Medical Genetics) have voiced strong opinions against the patenting of human genes. A particular concern of the medical genetics community is the impact of gene patenting on accessibility to high-quality genetic testing. There has been significantly less media attention and public discussion of licensing practices (e.g., exclusive versus nonexclusive) and their role in promoting or limiting access to genetic testing. Current US government policy strongly encourages universities to commercialize inventions funded by federal grants (Bayh-Dole Act, 1980). Best Practice models for technology licensing have recently been developed by the National Institutes of Health and by the Association of University Technology Managers, and strongly encourage nonexclusive licensing strategies except in cases where this model will not lead to successful commercialization. In the case of genetic testing, nonexclusive licensing strategies (e.g., CF gene) have the significant advantages of encouraging multiple laboratories to make the test readily available, encouraging test improvement, and creating cost-competition. Individual investigators involved in gene discovery, and patient advocacy groups collaborating with academic investigators, have the opportunity to influence the accessibility of diagnostic testing by strongly encouraging their institutions to follow the National Institutes of Health and Association of University Technology Managers Best Practice models of nonexclusive licensing for diagnostic rights to human gene patents. Genet Med 2008:10(5):314-319.
\end{abstract}

Key Words: genetic testing, Bayh-Dole Act, gene patents, licensing models

A major issue to be considered in the development and accessibility of quality clinical testing for all genetic diseases is that of gene patenting and subsequent licensing strategies. The ethical and legal issues of gene patenting have been quite controversial, and the American College of Medical Genetics has an official position statement against gene patenting (www.acmg. net). In 2006, the popular author Michael Crichton weighed in on this topic in his book Next, ${ }^{1}$ voicing strong opposition to virtually all commercialization of scientific discovery but specifically targeting gene patents and the Bayh-Dole Act of 1980 (discussed below). Breast cancer genetic testing involving the $B R C A 1$ and $B R C A 2$ genes, whose US diagnostic rights were licensed exclusively to Myriad Genetics, has received substantial negative media coverage ${ }^{2}$ and scientific criticism. ${ }^{3}$ It has been argued that a genetic testing monopoly restricted to a single diagnostic laboratory, results in no ability to obtain an independent confirmation of a test result (i.e., a "second opin-

\footnotetext{
From the Department of Human Genetics, Emory University School of Medicine, Atlanta, Georgia.

David H. Ledbetter, PhD, Department of Human Genetics, Emory University School of Medicine, Atlanta, GA 30322.E-mail: dledbetter@genetics.emory.edu.

Disclosure: The authors declare no conflict of interest.

Submitted for publication January 23, 2008.

Accepted for publication March 4, 2008.
}

DOI: 10.1097/GIM.0b013e3181729dab ion") and provides little incentive for test improvement or price competition. ${ }^{4,5}$

There are many recent publications and publicly accessible position articles addressing issues in human gene patenting and licensing. Many of these focus on the potential impact of gene patents as obstacles to further human genetics research, most concluding that there is little evidence for significant negative impact. ${ }^{6}$ However, in the area of clinical genetics testing, there are a number of case studies and surveys indicating that clinical genetics testing laboratories have dropped tests from their menus or chosen not to set up particular genetic tests because of gene patent issues. ${ }^{4}$

In this article, I will briefly review government and university policies regarding commercialization of inventions, and the relative impact of gene patenting versus licensing strategies in limiting access to genetic testing. Individual investigators, along with patient advocacy groups collaborating with academic investigators, can and should participate in the commercialization of their inventions (e.g., gene discovery) to help ensure the greatest access to diagnostic testing resulting from their invention. There are now several Best Practice models for licensing relevant to human gene patents and genetic testing available for investigators and advocacy groups to use to support their arguments in favor of nonexclusive licensing strategies. 


\section{US GOVERNMENT POLICY ON COMMERCIALIZATION OF INVENTIONS AT UNIVERSITIES: BAYH-DOLE ACT (1980)}

Among genetics researchers and clinicians, there is often a lack of understanding of the US government's attitudes toward patent policy and technology transfer involving universities. The major funding source for biomedical research, including human genetics, is the National Institutes of Health (NIH). It is sometimes argued that because many human gene discoveries are publicly funded by taxpayers through the NIH, it is inappropriate for academic institutions or private companies to profit from these discoveries through gene patents and licensing of this technology. However, the US government has passed legislation intended to strongly encourage universities to commercialize their research discoveries as a method to stimulate economic development within the United States and to serve the public good. This legislation, the Bayh-Dole Act, was enacted in 1980 and gave universities the option to own, manage, and profit from inventions made using federal funding (Fig. 1). The US government retains no ownership and receives no direct financial compensation for their investment in the research, but benefits indirectly through increased taxes paid by the private businesses involved in the commercialization of new technology and services. The only restrictions placed on universities were that they must show preference to commercialization partnerships with US based companies and especially small businesses.

Each university receiving federal research funding must comply with the Bayh-Dole Act, and all major medical schools and universities have developed Technology Transfer Offices since the enactment of Bayh-Dole. At many universities, individual faculty members may not have discretion over whether or not to file a patent on an invention (such as a gene discovery), but are required by university policy to report any invention that has potential commercial value. The university usually owns all rights to inventions by full-time faculty members, but most universities now have specific policies for sharing royalty income with faculty and staff inventors.

\section{Key Features and results of Bayh-Dole Act (1980)}

1. Gave universities the option to own intellectual property funded by federal government, with encouragement to commercialize discoveries for public good and economic growth.

2. Universities created Technology Transfer offices to commercialize discoveries.

3. Universities developed Intellectual Property (IP) policies which generally state:

- University owns all IP developed by faculty.

- Faculty are required to promptly disclose to university any inventions which may have commercial value, and for some, the decision to file a patent on a gene may not be the investigator's.

Fig. 1. Key features of the Bayh-Dole Act (1980) and university responses to this legislation as it relates to gene patenting and commercialization.
The intent of Bayh-Dole was that discoveries made by universities using federal funding would benefit the general public in terms of new products and services. For most genetic testing, this "commercialization" process does not require gene patents and licensing to ensure that new clinical testing services become widely available and may often have the opposite effect of greatly limiting access when exclusive licensing strategies are followed (see below).

\section{IMPACT OF COMMERCIALIZATION IN GENETIC TESTING}

The commercial manufacturing sector has been critically important to the development and manufacture of essential instrumentation, reagents, and kits for genetics testing laboratories. Major contributions include the invention and/or commercialization of polymerase chain reaction, DNA sequencing, fluorescence in situ hybridization, and microarray technologies, to name just a few. The successful commercialization of these technologies has made major contributions to the rapid growth and availability of many new genetic tests in the last 20 years.

In the diagnostic laboratory service sector, genetic testing has become a large and highly competitive business in the last two decades, including large national referral laboratory companies and numerous small genetics testing start-ups. A significant contributor to the growth of national reference laboratories was the widespread availability of overnight courier service, which obviated the need for most genetic testing to be performed within local hospital or medical school laboratories.

A positive outcome of the increased availability and competition for many genetic tests has been the improvement in some areas of customer service, e.g., laboratory turnaround times. In cytogenetics, routine prenatal chromosome analysis used to have average turnaround times of 3-4 weeks, but improved to 7-10 days after this standard was introduced by private genetics testing companies. This significant improvement did not require any major technology innovations, but simply a cultural change forced on academic laboratories by competition from the private sector.

A major concern regarding private sector involvement in genetic testing is the development of a monopoly, in which a single, for-profit laboratory is the only source of genetic testing for a given genetic disease. The most publicized example of this has been the case of BRCA1 and BRCA2 testing by Myriad Genetics in the United States. ${ }^{2}$ Concerns expressed regarding genetic testing monopolies include (1) potentially limited access, (2) no opportunity for independent confirmation of a test result (i.e., "second opinion"), (3) no price competition, and (4) less incentive to improve the genetic test. This latter concern was highlighted by a comprehensive molecular study of women at high risk for breast cancer who had normal genetic testing results through Myriad Genetics. Of 300 probands analyzed, $17 \%$ showed previously undetected mutations in 
$B R C A 1, B R C A 2$ or other genes known to be associated with breast cancer. ${ }^{3}$

Although a patent on a human disease gene is a necessary condition for a diagnostic monopoly to occur, it is not sufficient in and of itself. The licensing terms are often more important influences on accessibility of diagnostic testing than the existence of a patent. Investigators at academic institutions who discover a new gene and file a patent have the option to pursue nonexclusive licensing strategies which allow multiple clinical laboratories to offer genetic testing. This provides royalty income to the institution, but preserves the availability of independent confirmation of test results and the incentives for test improvements and cost-competitiveness. One of the best examples of successful nonexclusive licensing strategies for human gene patents is the CF gene (see below).

\section{STATUS OF HUMAN GENE PATENTS IN THE UNITED STATES}

A detailed discussion of US Patent law and issues related to human gene patenting is beyond the scope of this article. A number of recent reviews and commentaries about the potential impact of human gene patenting on research ${ }^{6}$ and on genetic testing ${ }^{4,5}$ are available. One of the most comprehensive discussions, including a series of case studies in clinical genetic testing for different patented human genes, is included in a draft statement by the Patenting and Licensing Committee of the European Society of Human Genetics (www.eshg.org).

The American College of Medical Genetics has also previously published a "Patent Primer" (www.acmg.org). Briefly, the US Patent and Trademark Office issues patents to individuals for inventions that represent a new and useful "process, machine, manufacture, or composition of matter" that meet standards for utility, novelty, and nonobviousness. By granting a patent, the government is giving the right to the inventor to exclude others from practicing the invention for a defined and limited time (currently 20 years from the date of filing). The inventor can grant permission to others to practice the invention via licensing, which can be done on an exclusive or nonexclusive basis.

Current US Patent law allows the patenting of human genes when the full length complementary DNA sequence is known, and in some cases where only partial sequence is known but information on biological function (e.g., disease association) is known such as expressed sequence tags or single nucleotide polymorphisms. Proposed legislation to rescind the patentability of human genes has been introduced in Congress but has so far not been successful.

Over 4000 human genes have now been patented in the United States, representing approximately $20 \%$ of the total predicted number of genes in the human genome. ${ }^{7}$ However, because of the public availability of the human genome sequence through the efforts of the Human Genome Project, the rate of filings and approvals for human gene patents has dropped. ${ }^{8}$ The requirements for patenting of a human gene have increased, even more so in the European Patent Office and the Japanese Patent Office than in the US Patent and Trademark Office.

It is of interest to note that the top two DNA patent holders in the United States are not commercial companies but an academic institution (the University of California system) and the US government. ${ }^{9}$ Among the top 30 US holders of DNAbased patents are 14 academic institutions or government agencies. This reflects the fact that a large proportion of biomedical research and gene discovery takes place within universities (funded by federal grants). Relevant to genetic testing issues, it is interesting to note that none of the major genetics diagnostic service companies (e.g., Genzyme Genetics, LabCorp, Quest, Athena Diagnostics) in the United States are among the top 30 DNA patent holders. Instead, these companies must obtain the diagnostic rights to human gene patents through licensing from academic institutions, emphasizing the importance of individual investigators, academic institutions, and patient advocacy groups in controlling the licensing strategy for their human gene patents (discussed further below).

\section{EXEMPTIONS}

There is a relatively common misconception that research uses of a patented invention, including laboratory techniques or human genes, are exempt from the requirement to obtain a license from the patent holder. Although this is true in the European patent process, it is not formally true in the United States. No research exemption exists in the US Patent act, but a very narrow legal allowance for research use was defined in a court case in 2002 (Madey versus Duke University). In practice, companies rarely sue universities over research usage of patented technologies, giving rise to the common misconception that a broad exemption exists. In the past 10 years, the $\mathrm{NIH}$ have published several guidelines regarding broad sharing of data from publicly funded research, further guiding universities to allow their inventions to be used freely by other university researchers. ${ }^{9}$ To formalize these research exemptions, both the $\mathrm{NIH}^{10}$ and the Association of University Technology Managers (AUTM) (www.autm.net) in their proposed Best Practices for licensing strategies (described below), strongly encourage universities to prospectively include a research exemption to all nonprofit institutions.

An exemption from gene patents for clinical genetic testing has been suggested by some authors. ${ }^{11,12}$ They argue that existing laws in the United States (Ganske-Frist Act, 1996) and Europe (Article 52(4)) which exempt physicians from the medical use of patented medical information when treating or diagnosing patients should apply to genetic testing. This argument has not been successfully used to date, and legislative attempts in the United States to extend Ganske-Frist to specifically include genetic testing have so far not succeeded.

Given the difficult and uncertain task of modifying patent law, it may be more practical to focus efforts on supporting the recent NIH and AUTM Best Practice models for research exemptions and nonexclusive licensing whenever possible. 


\section{LICENSING STRATEGIES: CFTR VERSUS BRCA MODELS}

The inventor/patent holder has the opportunity to grant licenses to others to practice their invention in return for upfront payments and/or ongoing royalty payments. These licenses may be broad or narrow in terms of fields of use (e.g., diagnostic versus therapeutic products or services), and may be exclusive or nonexclusive. In the majority of cases, a forprofit company prefers to obtain an exclusive license to an invention to provide the most protection for their investment in the development of new drugs or diagnostic tests. In the case of drug development, the granting of an exclusive license may be necessary and appropriate as no company would be willing to invest the large sums of money necessary to develop a new drug without protection from competitors. However, for diagnostic testing for most human diseases, the required up-front investment is modest and it is hard to justify an argument for an exclusive licensing arrangement.

An interesting aspect of the Bayh-Dole Act is that it gave universities a great deal of freedom in determining the best way to commercialize their inventions. Most relevant to this discussion, there were no guidelines or Best Practice recommendations for licensing of their inventions. For diagnostic testing rights for human gene patents, one can compare the impact of a nonexclusive versus exclusive licensing strategy.

The gene for cystic fibrosis, CFTR, was identified in 1989 by a collaborative group of academic investigators, and a patent was filed and issued to the Hospital for Sick Children (Toronto) and the University of Michigan (Table 1). The choice by the inventors and their institutions to license diagnostic rights on a nonexclusive basis has led to widespread adoption of diagnostic testing and carrier screening by a variety of homebrew and manufactured kit approaches.

In contrast, the diagnostic testing rights to BRCA1 and $B R C A 2$ genes were licensed exclusively to Myriad Genetics, Inc., in Salt Lake City, Utah. In this case, scientists working at Myriad were directly involved in the gene discoveries in collaboration with university and government collaborators, and Myriad is one of the assignees for the key patents to these two genes. It is understandable that the for-profit company (Myriad) would seek exclusive diagnostic rights, but more open nonexclusive strategies could have been influenced by the academic and government inventors and assignees in these cases.

Several other examples of human gene patents and their licensing strategies are listed in Table 1. The mixture of exclusive and nonexclusive licensing strategies for diagnostic testing rights to human genes, even within individual institutions (e.g., Baylor College of Medicine, Houston), supports the notion that individual investigators and perhaps patient advocacy groups can influence licensing strategy.

This is also supported by the unusual and uncertain status of genetic testing for Rett Syndrome currently in the United States. In 1999, investigators at Baylor College of Medicine and Stanford University identified mutations in the previously known gene MECP2 as the cause of Rett Syndrome. ${ }^{13} \mathrm{~A}$ patent was issued to these investigators for a "Method of screening Rett Syndrome by detecting a mutation in MECP2" in 2004. Perhaps in part due to financial support and involvement of the International Rett Syndrome Association and the investigators' commitment to make genetic testing widely available for this disorder, licensing for diagnostic testing was made available on a nonexclusive basis, and a number of academic and commercial laboratories began offering MECP2 mutation analysis by full gene sequencing. In 2004, another group reported a previously unidentified open reading frame for $M E C P 2$, referred to as $M E C P 2 E 1$, encoding a novel isoform for the protein. ${ }^{14}$ Two of the 12 coauthors of this publication have filed US Patent applications $(11 / 352,153)$ for this new open reading frame and isoform, claiming rights to genetic testing based on this incremental new information regarding a known relationship between a human gene and specific disease. These investigators have exclusively licensed the diagnostic rights to a single, for-profit diagnostic company (Athena Diagnostics, Inc.) which is currently notifying other US laboratories of its anticipated exclusive rights to provide genetic testing for Rett Syndrome and other neurodevelopmental disorders using $M E C P 2 E 1$. It is unclear whether this limited new information on the Rett gene will be sufficient to be granted a US Patent, but it is clear that the choice to pursue an exclusive licensing agree-

Table 1

Examples of licensing strategies by academic patent-holders (assignees)

\begin{tabular}{|c|c|c|c|}
\hline Gene & US patent number & Assignees & Licensing \\
\hline CFTR & $6,201,107$ & Hospital for Sick Children, University of Michigan & Nonexclusive \\
\hline$B R C A 1$ & $5,710,001$ and others & $\begin{array}{l}\text { Myriad Genetics, University of Utah, US Department of } \\
\text { Health and Human Services }\end{array}$ & Exclusive \\
\hline$B R C A 2$ & $5,837,492$ and others & Myriad Genetics, University of Pennsylvania & Exclusive \\
\hline CMT1A & $5,306,616$ and others & Baylor College of Medicine & Exclusive \\
\hline SCA1, SCA7, SCA8 & $5,741,645,6,280,938,6,524,791$ & University of Minnesota, Baylor College of Medicine & Exclusive \\
\hline FMR1 & $6,107,025$ & Baylor College of Medicine, Emory University & Nonexclusive \\
\hline MECP2 & $6,709,817$ & Baylor College of Medicine, Stanford University & Nonexclusive \\
\hline$M E C P 2 E 1$ & Pending & Hospital for Sick Children & Exclusive \\
\hline
\end{tabular}


ment for diagnostics is counter to the intent of the original investigators and patient advocacy groups involved in the main discovery.

\section{BEST PRACTICE MODELS FOR LICENSING HUMAN GENE PATENTS}

The NIH initially left universities receiving extramural research funding completely on their own to determine their licensing policies. This created an interesting difference in licensing patterns of human genes which were discovered and patented by investigators in the NIH Intramural program, compared with investigators at universities supported by the NIH Extramural program. Approximately $15 \%$ of NIH research funds support government scientists in the Intramural research program centered in Bethesda, MD. The NIH Intramural program has had a long-standing policy requiring nonexclusive licensing on all inventions as the primary method of making inventions available to others. Only in cases where a nonexclusive licensing strategy fails are narrow exclusive licenses considered to commercialize an invention.

In 2005, the NIH published a "Best Practices for the Licensing of Genomic Inventions" guideline which encourages, but does not require, the extramurally funded community (all universities receiving NIH grants) to negotiate nonexclusive licenses whenever possible. ${ }^{10}$ It also includes provisions to ensure that the invention (e.g., gene) is freely available for further research to all.

In 2007, the AUTM issued a White Paper of nine points to consider in licensing technology (www.autm.net). There is significant overlap between the principals discussed in this White Paper and the Best Practices for Genomic Inventions published by NIH, particularly an emphasis on nonexclusive licensing wherever possible. This White Paper was endorsed by many of the major universities with significant human gene patent portfolios, and by the American Association of Medical Colleges.

\section{ROLE OF INDIVIDUAL INVESTIGATORS, ACADEMIC INSTITUTIONS, AND PATIENT ADVOCACY GROUPS IN GENETIC TEST ACCESSIBILITY}

Many universities have endorsed the AUTM White Paper published last year and should have familiarity with the $\mathrm{NIH}$ statement regarding Best Practices for licensing of genomic inventions. Given this, one can envision an increasing trend toward nonexclusive licensing for human gene patents particularly for diagnostic usage.

There is an important role for individual human genetics investigators, along with patient advocacy groups, to proactively encourage universities to ensure the broadest access for genetic testing through nonexclusive licensing. Many individual faculty members are unfamiliar with the commercialization process following an invention such as a gene discovery, although most researchers are aware of their university's requirement to file an Invention Disclosure which might lead to a patent application and subsequent commercialization of diagnostic and therapeutic rights to the invention.

Investigators for rare genetic diseases often work very closely with families volunteering for their research and in many cases directly with an organized patient advocacy group for a specific genetic disease. A lack of communication regarding commercialization philosophies and goals between investigators and families or advocacy groups can lead to significant conflicts regarding access to genetic testing, as was the case for Canavan disease. The gene for Canavan was identified in 1994 by investigators at Miami Children's Hospital Research Institute and a patent was filed and issued without the knowledge or participation by families who had voluntarily participated in the research. The hospital then chose to retain exclusive rights to diagnostic testing which was provided at prices considered unreasonably high by the genetics and patient communities. Significant pressure and legal actions were subsequently brought on the hospital to alter the pricing of the test to make it more accessible to the community, an issue which was successfully settled out of court.

A new model for proactive involvement of a patient advocacy group in human gene discovery and patenting is that of PXE International, an organization representing families with pseudoxanthoma elasticum. In this case, members of the advocacy organization became formal collaborators on the research effort to identify the responsible gene and are named on the gene patent as inventors. ${ }^{15}$ The investigators involved in the research assigned the rights to the gene to the foundation, so that it can ensure that the commercialization process for diagnostics and therapeutics is done in the best interests of families with this disease.

Further educational efforts are needed to make investigators and advocacy groups more aware of their opportunity and obligation to participate in the commercialization process related to human gene discovery. Only this participation can ensure that this process serves the needs and goals of the families and investigators to make quality genetic testing accessible to all.

\section{References}

1. Crichton M. Next. New York: Harper Collins; 2006.

2. Caulfield T, Bubela T, Murdoch CJ. Myriad and the mass media: the covering of a gene patent controversy. Genet Med 2007;9:850-855.

3. Walsh R, Casadei S, Coats KH, Swisher E, et al. Spectrum of mutations in BRCA1, BRCA2, CHEK2, and TP53 in families at high risk of breast cancer. JAMA 2006;295: 1379-1388.

4. Cho MK, Illangasekare S, Weaver MA, Leonard DGB, et al. Effects of patents and licenses on the provision of clinical genetic testing services. J Mol Diagn 2003;5: $3-8$.

5. Verbeure B, Matthijs G, Van Overwalle G. Analysing DNA patents in relation with diagnostic genetic testing. Eur J Hum Gen 2006;14:26-33.

6. National Academy of Sciences (NAS). Reaping the benefits of genomic and proteomic research, intellectual property rights, innovation and public health. Washington, DC: NAS, 2006.

7. Jensen K, Murray F. Intellectual property landscape of the human genome. Science 2005;310:239-240.

8. Hopkins JJ, Mahdi S, Patel P, Thomas SM. DNA patenting: the end of an era? Nat Biotechnol 2007;25:185-187.

9. Pressman L, Burgess R, Cook-Deegan RM, McCormack SJ, et al. The licensing of DNA patents by US academic institutions: an empirical survey. Nat Biotechnol 2006; 24:31-39. 
10. National Institutes of Health (NIH). Best practices for the licensing of genomic inventions. Federal Register 2005;70:18410-18415.

11. Matthijs G. The European opposition against the BRCA gene patents. Fam Cancer 2006;5:95-102.

12. Klein RD. Gene patents and genetic testing in the United States. Nat Biotechnol 2007;25:989-990.

13. Amir RE, Van den Veyer IB, Wan M, Tran CQ, et al. Rett syndrome is caused by mutations in X-linked MECP2, encoding methyl-CpG-binding protein 2. Nat Gen 1999;23:185-188.

14. Mnatzakanian GN, Lohi H, Munteanu I, Alfred SE, et al. A previously unidentified MECP2 open reading frame defines a new protein isoform relevant to Rett syndrome. Nat Gen 2004;36:339-341.

15. Terry SF, Terry PF, Rauen KA, Uitto J, et al. Advocacy groups as research organizations: the PXE International example. Nat Rev Gen 2007;8:157-164. 